\title{
Development of Learning Tools for Mathematics Content Based on a Contextual Approach to Improve the Higher-Level Thinking Ability of 5th Grade SDN Students 047179 Kutagerat
}

\author{
Melina Br. Sembiring' ${ }^{1}$, Mulyono², Zulkifli Matondang ${ }^{3}$ \\ ${ }^{1,2,3}$ Universitas Negeri Medan, Indonesia \\ melinasembiring375@gmail.com
}

\begin{abstract}
This research aims to knowing the validity of learning tools developed using a contextual approach in improving the highorder thinking skills of students of SDN 047179 Kutagerat; know the practicality of the learning tools being developed; know the effectiveness of learning tools; and knowing the increase in students' higher order thinking skills using learning tools based on a contextual approach. This study uses the Thiagarajan 4-D development model. VaThe lidity of learning media used descriptive statistical analysis. Data analysis to find out how the increase in the score of increasing student learning outcomes can be obtained from the normalized gain index data. The results showed that: (1) The results of the validator's assessment of the four mathematics learning tools based on the contextual approach that had been developed were as follows: (a) the linguist's assessment obtained an overall average of 93\%; $(b)$ the design expert's assessment obtained an overall average of 93.13\%; (c) the material expert's assessment obtained an overall average of $96 \%$. The results of the validation of the four learning tools by the validator are in the criteria of "very feasible" to be used in the field; (2) The results of the response of the fifth grade teacher at SDN 047179 Kutagerat to the learning tools obtained an average percentage of $89 \%$. The result of the average percentage of the overall field test on student responses is $86 \%$ with "very good" criteria. This means that the learning tools are practical and can meet the demands of learning needs; (3) after learning using learning tools obtained on average 92, it was concluded that the students' abilities experienced a high significant increase and reached the KKM as expected; and (4) the average N-Gain gain is 0.718 . The average is categorized as high because if $0.30<g$ $<0.70$ it is categorized as high. It was concluded that students who use mathematics content learning tools based on a contextual approach in the learning process can improve learning outcomes or students' higher order thinking skills in the fraction count operations material.
\end{abstract}

Keywords

learning tools, mathematics contextual approaches, and higher-5th level thinking skills

\section{Introduction}

Since the last decade, the character of education has become an important issue. This problem is caused by the emergence of components of the nation's behavior phenomenon, especially the younger generation who tend to prioritize hedonistic traits that are not in accordance with the religious principles of social principles, legal rules and norms that apply in Indonesian society (Sudrajat, 2011). In the context of nationality, this behavior shows the fading values of the national spirit among the younger generation which are 
increasingly evident. The act of not paying attention to the national symbol, not memorizing Pancasila, disliking and even not knowing the national anthem, not recognizing national heroes, not being proud and not knowing the nation's culture, would be even worse (Pradana et al. 2020).

From the results, Indonesia participated in PISA (The Program for International Student Assessment) from 2000 to 2015 with results that did not show much change in each of its participation. In 2015 Indonesia was ranked 69 out of 76 countries with a score of 386 with an average score of 490 (PISA, 2015: 1). For TIMSS (Trends in International Mathematics and Science Studies) in 2015, Indonesia is ranked 45th out of 50 countries with a score of 397 (Puspendik, 2015: 2). This proves that the research conducted by PISA and TIMSS states that the results in the field of mathematics studies are still not satisfactory and are classified as still low.

In fact, the current learning outcomes, especially student mathematics, are still low because in the mathematics learning process the teacher concentrates too much on the practice of solving problems. In learning activities, teachers are accustomed to explaining concepts informatively, giving examples of questions and giving practice questions. The teacher is the center of the activity, while the students tend to be passive during the learning activities. Students only listen, record lessons and do questions.

In learning mathematics, teachers are expected to provide easy concepts to their students in order to understand and solve problems with logical, systematic, and structured thinking habits. The teacher considers that students are better at mastering the overall material than developing thinking skills in the mathematics learning process. Focusing on fraction material, most teachers teach abstractly so that most students are confused in following the mathematics learning process with fraction material. Therefore, grade V SD students have poor learning outcomes.

High-level thinking in Bloom's taxonomy (2001 edition) begins with a cognitive process: analyzing, evaluating to creating something. At each level of the cognitive process students subject to metacognitive knowledge, ranging from strategic knowledge, knowledge about cognitive tasks, and knowledge about oneself. Analyzing is the process of breaking down material into parts and detecting how the parts are related to one another and related to the overall structure or purpose. The process of analyzing this involves differentiating, organizing, and attributing. (Prasetyo et al. 2019)

Kurniati's research results, (2016) High Level Thinking Ability of Junior High School Students in Jember Regency in solving PISA standard questions based on the indicators that have been compiled. High-level thinking skills in this study include logic and reasoning skills, analysis, evaluation, and creation.

Based on a preliminary study through classroom observations and interviews conducted by researchers with several teachers and fifth grade students at SDN 047179 Kutagerat, it is said that students feel bored learning mathematics because the teaching materials used in learning have not used learning methods or models, the learning process that occurs is not associated with daily life, the low student learning outcomes in mathematics, the contextual approach to fractions based learning tools has not been developed. While the graduation standard that must be achieved by students in learning mathematics with a $K K M \geq 75$. From the results of the value data obtained by the researcher, students who reached the KKM were $51 \%$ and those who did not reach the KKM were $49 \%$. From the above statement it can be gathered that the results of learning mathematics are not good,

Based on the results of my observations, grade V teachers at SDN 017179 Kutagerat have not been able to make good use of learning tools, it can be seen from the learning 
tools used by the teacher. The lesson plan (RPP) used by the teacher still uses teachercentered lectures, so it is necessary to use an innovative learning model to activate students in the learning process. In addition, the learning steps do not refer to the learning model listed in the lesson plan and do not involve active student activities in learning mathematics through learning steps in core activities.

There needs to be a solution to overcome it, one of which is by developing learning tools. The purpose of the developed learning tools is to obtain good mathematics learning outcomes and to improve students' higher order thinking skills. By using learning tools that have been designed attractively, students can develop better learning methods so as to gain success in the mathematics learning process. Thus the development of learning tools is a process to determine or create certain conditions that cause students to interact in such a way that behavior changes.

Based on the explanation above, it appears that the development of learning tools is very important to support the learning process. According to Devi (2009: 5), every teacher in an education unit is obliged to arrange learning tools that are interactive, inspirational, fun, and motivate students to participate actively. The contextual approach to learning mathematics seeks to change the conditions above, namely by creating learning scenarios starting from the real-life context of students. Furthermore, the teacher facilitates students to bring objects into real life into concepts, by means of question and answer, discussion, inquiry, so that students can construct these concepts in their minds. With the contextual approach based learning tools, it is expected to make mathematics learning with fraction material more meaningful, making students who were confused become more understanding and understanding so that the higher order thinking skills obtained by grade V students at SDN 047179 Kutagerat are better.

\section{Review of Literature}

\subsection{The Nature of Learning Mathematics}

A person will not want to do learning if not of his own will, meaning that learning will not want to do learning if it is done by coercion. Jihad (2008: 153) aims at students studying mathematics, namely having the ability to:
a. Using algorithms (job procedures);
b. Perform mathematical manipulations'
c. Organizing data;
d. Make use of symbols, tables, diagrams and graphs;
e. Recognizing and finding patterns;
f. Draw a conclusion;
g. Creating mathematical sentences or models'
h. Make a wake-up interpretation in fields and spaces;
i. Understand measurement and units;
j. Using calculation tools and math aids.

According to Jihad (2008: 154), the orientation of mathematics learning currently focuses on efforts to build positive perceptions in learning mathematics among students. Teachers are encouraged to provide rational descriptions of the ease and usefulness of mathematics for students in an atmosphere that provides comfort in the midst of the difficulties faced by children while studying mathematics, so that students can learn well and produce adequate achievements. So it can be concluded that the essence of mathematics learning is a learning process that is built by the teacher to improve mathematical skills in solving mathematical problems related to everyday life and can 
improve thinking skills, creativity skills, the ability to construct knowledge and problem solving abilities.

\subsection{Learning Tools}

Learning devices are teaching materials that are packaged as materials to be presented in the learning process. According to the Ministry of National Education (2008: 302) that teaching materials or learning tools are "all forms of materials used to assist teachers / instructors in carrying out teaching and learning activities. The material referred to can be in the form of written material or unwritten material ". The learning tools needed in managing the teaching and learning process can be in the form of: syllabus, lesson plans (RPP), student worksheets (LKPD). Evaluation Instruments or Learning Outcomes Test (THB), learning media and student textbooks (Trianto, 2011: 201).

Every teacher in an education unit is obliged to develop interactive, inspirational, fun learning tools and motivate students to participate actively. From this description it can be concluded that the learning device is a collection of materials and facilities used in the teaching and learning process. In this study, the learning tools were in the form of a Learning Implementation Plan (RPP), Teacher's Book (BG), Student Book (BS) and Student Activity Sheets (LKPD).

\subsection{Higher Level Thinking Ability}

High Order Thinking Skills (HOTS) is a thought process that requires students to manipulate information and ideas in certain ways that give them new understanding and implications (Gunawan, 2012: 171). Limpan describes higher-order thinking involving critical and creative thinking that is guided by truth ideas, each of which has meaning. Critical and creative thinking are interdependent, as are criteria and values, reason and emotions (Kuswana, 2012: 200).

According to Ernawati (2017: 196-197), higher order thinking or Higher Order Thinking Skills (HOTS) is a way of thinking that no longer only memorizes verbally but also interprets the essence of what it contains, to be able to interpret meaning requires an integralistic way of thinking. With analysis, synthesis, associating and drawing conclusions towards the creation of creative and productive ideas. Based on some of these opinions, it can be concluded that Higher Order Thinking Skills (HOTS) are the ability to think which is not just remembering, restating, and also referring without processing, but the ability to think critically to examine information creative and able to solve problems.

\subsection{Contextual Approach}

A contextual approach to learning or better known as Contextual Teaching and Learning (CTL) is a "learning concept by helping teachers to link teaching material with students' real world situations, which can encourage students to make connections between the knowledge learned and its application in student life. "(Sardiman, 2009: 222). "yes, socially and culturally". The explanation above can be clarified by Saifuddin (2009: 163) that "contextual learning is in the form of: (1). Emphasis on the process of involving learners to find material, (2). Encourage students to find a relationship between material and real life and (3). Encourage students to be able to apply it to life".

From the above understanding, it can be concluded that contextual learning is a learning concept that helps teachers connect the subject matter they teach with students' real-world situations and encourages students to make connections between their knowledge and its application in everyday life. 


\section{Research Methods}

This study uses the Thiagarajan 4-D development model (define, design, develop, and disseminate). This research will be carried out at SDN 047179 Kutagerat, located in Kutagerat Village, for fifth grade students in the odd semester of the 2020/2021 academic year. The research was carried out in 2020. The subjects in this study were 20 students of class V SDN 047179 Kutagerat, totaling 20 students in the 2020/2021 academic year, while the object in this study was a learning tool based on a contextual approach to fractions material. Learning device validation sheets are used to obtain data about the quality of learning devices based on expert assessments. Validation sheets for lesson plans, teacher books, student books, student activity sheets. The test tested in this study measured students' higher order mathematical thinking skills. The choice of the form of the question is in the form of multiple choice test in which the form contains an indicator of higher order mathematical thinking skills. Statistically validated questions first with validity with the product moment correlation formula andReliability Alpha formula are used. To see the validity of the learning media used descriptive statistical analysis based on the average score of each learning tool based on a contextual approach that has been validated by experts. After knowing the results of the calculation of the percentage of the feasibility of the learning device, then interpreted based on the validator assessment interpretation criteria. Learning tools based on the contextual approach are said to be feasible if all aspects of the validation get a minimum percentage of $60 \%$ (feasible category). One of the criteria for practicality is by looking at the responses from users, namely teachers and students. Data analysis to find out how the increase in the score of increasing student learning outcomes can be obtained from the normalized gain index data.According to (Hake in Sundayana, 2014: 151) "The Gain Normality Test is a test that can provide an overview of the increase in learning outcomes scores between before and after the application of a treatment".

\section{Results and Discussion}

\subsection{Validity of Learning Tools Based on Contextual Approach}

The process of developing mathematics content learning tools is very important to be carried out based on a needs analysis. According to Hans Frudhental mathematics is part of human activities (Hadi, 2017). In line with the research results of Sa'diyah (2018: 207), it is stated that learning tools are needed that can help students and teachers to optimize learning in the classroom.

The process of developing learning tools based on a contextual approach consists of several stages. The first stage of definition carried out is student analysis (learner analysis). Student analysis is carried out to understand student characteristics, namely the level of ability or intellectual development and skills or social skills that are already owned and can be developed to achieve learning objectives. Next, analysis of the media requirements defined in learning. The idea that the product developed is in accordance with the needs in the field, then analyzes the concept of the learning device that will be developed. Formulation of learning objectives (specifying instructional objects) and formulation of learning tools.

The second stage is designing (design) learning devices. Initial product development was carried out by making mathematics learning tools based on a contextual approach. This is done in order to guide the course of the production of the product before the development stage. (1) Constructing criterion-referenced test (compiling test criteria- 
reference), this step is a bridge connecting stage I and stage; (2) Media selection, the selection of appropriate media to present the content of the lesson. This process includes adapting concept analysis and task analysis to the character of the student, production sources, distribution plans regarding the properties of the media; (3) Format selection, this step is closely related to the previous media selection. The term learning format itself refers to a combination of media, teaching strategies, and usage techniques. In this case the media is in the form of mathematics content learning tools based on a contextual approach to improve students' higher order thinking skills; (4) Initial design (initial completion), the third stage is the development of learning tools. Development of learning tools for mathematics content based on a contextual approach. Presenting the basics of learning through appropriate media and in the appropriate order. Based on the analysis at SDN 047179 Kutagerat that the fifth grade teacher of SDN 047179 Kutagerat (100\%) stated that they knew the mathematics content learning device based on the contextual approach that was developed, while 17 people or $85 \%$ of the total number of students stated that they were not familiar with learning tools for learning mathematics content based on a contextual approach that was developed. developed. Teachers and students (100\%) stated that they had never used mathematics learning tools based on a contextual approach in the learning process. The teacher $(100 \%)$ stated that they needed a mathematics content learning device based on a contextual approach that was developed and $90 \%$ of students stated that they needed a mathematics content learning device based on a contextual approach developed in the learning process. Products developed for teacher handbooks (teacher books), student books, LKPD, and lesson plans. Several mathematics content learning tools based on a contextual approach were developed with the aim of improving higher order thinking skills. Therefore, the validity and practicality of the learning tools developed are the most fundamental things to determine the effectiveness of the learning tools.

\subsection{Validity of Learning Tools Based on Contextual Approach}

Getting a feasible learning product must be validated by an expert on the learning device. Akbar (2013) states that validation of learning devices is carried out by means of a person or several learning experts providing an assessment of learning tools through expert validation instruments to assess the suitability of learning devices with their theory and provide input for improving learning devices. In line with that, Rochmad (2012) also argued that the validity of the learning device was said to be valid if the learning device was declared fit for use with revision or without revision by the validator.

According to Clements and Cord in (Crisp, 2016) assessment is an important component in learning and the learning environment and has a role in determining learning outcomes. The assessment process in learning is carried out to obtain data about the development of student learning outcomes. Therefore, the development of learning tools for mathematics content based on a contextual approach is expected to be a learning tool for quality assurance, quality control and quality improvement in certain learning systems. learning tools developed must have requirements and are suitable to be used as learning products.

The feasibility of learning mathematics content based on a contextual approach is obtained from the results of validation and assessment given by linguists, design, and material experts. The total number of validators is three people. The criteria for each assessment indicator as a whole are determined by the average score of each expert's assessment criteria. The results of the assessment were analyzed to determine whether or not the mathematics content learning device was feasible based on a contextual approach 
to improve the higher order thinking skills of fifth grade students of SDN Kutagerat. Feasible or not like the learning tools that have been developed, the product was tested for fifth grade students of SDN 047179 Kutagerat. After that, the product is given to the teacher to find out the results of the assessment and suggestions given.

The learning tools for mathematics content based on the contextual approach developed consist of four products, namely teacher books, student books, LKPD, and lesson plans. Design expert validators validate for lesson plans (RPP), teacher books (BG), student books (BS), and student activity sheets (LKPD). The results of the assessment aspects of each learning device obtained from three experts will be described as follows.

\section{a. Result of Validation of Learning Tool Language Experts}

Data validation results by learning device linguistconducted by M. oky Fardian Gafari who is a lecturer at the State University of Medan. The results of the linguist's validation of the teacher's book learning tool from the seven assessment indicators obtained an average percentage of $96 \%$ in the "very feasible" criteria. The total average number of the results of the validation indicators for student book assessments is $93 \%$ in the criteria of "very feasible". LKPD validation by linguists obtained an average overall assessment indicator of $89 \%$ in the "very feasible" criteria. The overall average number of linguist validation results on the RPP assessment indicator is $92.85 \%$ which is in the "very feasible" criteria. Therefore, the overall average of mathematics content learning tools based on the contextual approach developed is $93 \%$ in the criteria of "very feasible".

\section{b. Expert Validation Results Learning Device Design}

The validator for the design of learning devices is carried out by Samsidar Tanjung who is a lecturer at the State University of Medan. Data from the expert validation on the design of learning materials for mathematics in detail can be seen in the research results and appendices.

The results of the final validation of the design expert on the teacher's book obtained an average overall aspect of $89.5 \%$ in the criteria of "very feasible". The average assessment of students' books for all aspects and indicators is $96 \%$ in the criteria "very worthy". The average LKPD assessment for all aspects and indicators is $94 \%$ in the criteria "very worthy". The total average of the results of the validation of the RPP design assessment indicators is $93 \%$ in the criteria of "very feasible". Therefore, the overall average of the results of the design expert's validation of learning tools in the form of teacher books, student books, student worksheets, and lesson plansis $93.13 \%$ are in the criteria of "very feasible" to be used in the field.

\section{c. Expert Validation Results Learning Device Design}

Validators for learning device material experts are carried out by Edy Surya who is a lecturer at the State University of Medan. Overall averagecontent assessment indicators from the teacher's book is $100 \%$ in the criteria "very worthy". Overall average content assessment indicators from the student book is $92 \%$ are in the criteria "very worthy". The overall average assessment of the LKPD indicator material is $97 \%$ in the criteria of "very feasible". The criteria for the six indicators for evaluating the content of the lesson plans by material experts obtained an average of $94 \%$ in the criteria of "very feasible". Hence, the overall average of the expert validation results $96 \%$ of the material for learning mathematics content based on a contextual approach is in the criteria of "very feasible" to be tested in the field and can meet the demands of learning needs. 


\subsection{Practicality Learning Media Based on a contextual approach}

The practicality of learning materials based on contextual approaches to improve the high-order thinking skills of fifth grade students of SDN 047179 Kutagerat can be seen from the results of teacher and student responses after learning using learning tools.

The practicality of the learning device in question is the ease in using the learning device. According to Windrianto, et al. (2017), it is practical if the user does not have difficulty in terms of presenting the material and using learning materials. According to Nieveen in Rochmad (2012), the practicality of a learning device being developed can be seen from the level of ease and assistance in its use. Practicality must meet the needs of users, in this case the users of these learning devices are teachers and students.

The results of the response or responses made by the teacher Class V SDN 047179 KutageratIt was concluded that the contextual approach-based mathematics learning device was included in the "very good" criteria with a total average percentage of $89 \%$ with the "very good" criteria. The results of the response from the fifth grade teacher at SDN 047179 Kutagerat to the mathematics content learning tool based on the contextual approach in detail can be seen in the appendix.

The results of field trials regarding student responses to learning tools that have been developed show that the average percentage results are obtained that the assessment of the learning assessment indicators has an average percentage $87 \%$, an indicator of material appraisal with averages $87 \%$, and presentation assessment indicators with averages $84 \%$. The result of the average percentage of the entire field test is $86 \%$ with the criteria of "very good" This means that the mathematics content learning device based on the contextual approach developed has an increase in development and can meet the demands of learning needs.

\subsection{Effectiveness Learning Media Based on a contextual approach}

Effectiveness learning tools for mathematics content based on a contextual approach the total acquisition score of 1842 with an ideal score of 2000, then the score obtained $92 \%$ and effectiveness before using an assessment instrument of $72.95 \%$. After learning by using mathematics content learning tools based on a contextual approach obtained on average $92 \%$. The lowest student score is 75 and the highest is 95 . Based on the average score of the student's posttest data above, it can be concluded that the student's ability has a high significant increase and reaches the KKM as expected.

The results of data analysis in the table above concluded that 20 students completed with a percentage of $100 \%$ of 20 students. The percentage of students' classical completeness (PKK) was obtained $100 \%$. This PKK is obtained from posttest student learning outcomes after using mathematics content learning tools based on a contextual approach. The results of the analysis of the effectiveness of student learning outcomes concluded that studentsV SDN 047179 Kutagerat has finished studying because of PKK $\geq 85 \%$. Similar to the results of Khasanah's research conclusions (2020), based on the classical completeness percentage of $100 \%$ fulfills the very good classification, learning tools in the form of video media are declared to be effectively applied in learning.

The average pretest score of students before using learning tools was 72.95 and the average posttest score of students after using learning tools was 92. The improvement in student learning outcomes was analyzed using N-Gain which was obtained from the pretest score and posttest score. The average $\mathrm{N}$-Gain gain was 0.718 . The average is categorized as high because if $0.30<\mathrm{g}<0.70$ it is categorized as high. It was concluded that students who use mathematics content learning tools based on a contextual approach in the learning process can improve learning outcomes or students' higher order thinking skills on fraction arithmetic operations. 


\section{Conclusion}

Conclusions from the results of development research Mathematical content learning tools based on the contextual approach stated earlier can be described as follows;

1. The validity of the mathematics content learning device based on the contextual approach to improve the high-order thinking skills of fifth grade elementary school students was seen from the results of expert validation of the learning tools. The results of the validator's assessment of the four mathematics content learning tools based on the contextual approach that have been developed are as follows: (a) the linguist's assessment obtains an overall average of 93\%; (b) the design expert's assessment obtained an overall average of $93.13 \%$; (c) the material expert's assessment obtained an overall average of $96 \%$. The results of the validation of the four learning tools by the validator are in the criteria of "very feasible" to be used in the field.

2. The practicality of learning devices is seen from the responses of teachers and students to the learning tools developed. The results of the response of the fifth grade teacher at SDN 047179 Kutagerat to the learning tools obtained an average percentage of $89 \%$. The result of the average percentage of the overall field test on student responses is $86 \%$ with "very good" criteria. This means that the learning device for mathematics content is based on a contextual approach that is developed practically and can meet the demands of learning needs.

3. The effectiveness of learning tools using a contextual approach in improving students' higher order thinking skills in mathematics is seen from student learning outcomes. After learning by using mathematics content learning tools based on a contextual approach obtained on average 92 . The lowest student score is 75 and the highest is 95 . Based on the average score of the student's posttest data above, it can be concluded that the student's ability has a high significant increase and reaches the KKM as expected.

The results of the data analysis concluded that the students who completed were 20 students with a percentage of $100 \%$ of the 20 students. The percentage of students' classical completeness (PKK) was obtained 100\%. The results of the analysis of the effectiveness of student learning outcomes concluded that the class studentsV SDN 047179 Kutagerat has finished studying because of PKK $\geq 85 \%$.

4. The improvement of students' high-order thinking skills using learning tools based on a contextual approach was analyzed using N-Gain which was obtained from the pretest score and the posttest score. The average N-Gain gain was 0.718. The average is categorized as high because if $0.30<\mathrm{g}<0.70$ it is categorized as high. It was concluded that students who use mathematics content learning tools based on a contextual approach in the learning process can improve learning outcomes or students' higher order thinking skills in the fraction count operations material.

\section{References}

Akbar, S. (2013). Instrumen Perangkat Pembelajaran. Remaja Rosdakarya: Bandung.

Ernawati, L. (2017). Pengembangan High Order Thinking (HOT) Melalui Metode Pembelajaran Mind Banking dalam Pendidikan Agama Islam. International Confrence on Islamic Civilization ans Society (ICICS. 189-202.

Depdiknas. (2008). Panduan Pengembangan Bahan Ajar. Jakarta: Direktorat Jenderal Manajemen Pendidikan Dasar dan Menengah.

Devi, P.K., et.al. (2009). Pengembangan Perangkat Pembelajaran. Bandung: P4TK IPA.

Gunawan, H. (2012). Pendidikan Karakter, Konsep dan Implementasi. Bandung: Alfabeta. 
Hadi, S. (2017). Pendidikan Matematika Realistik, Teori, Pengembangan dan Implementasinya. Jakarta: Rajawali Pers.

Jihad, A. (2008). Pengembangan Kurikulum Matematika (Tinjauan Teoritis dan Historis). Yogyakarta: Multi Pressindo.

Kurniati, (2016). Kemampuan Berpikir Tingkat Tinggi Siswa SMP Di Kabupaten Jember Dalam Menyelesaikan Soal Berstandar Pisa. Jurnal Penelitian dan Evaluasi Pendidikan. 20 (2):142-155.

Khasanah, N. (2020). Pengembangan Media Video Berbasis Pendekatan Kontekstual Subtema "Aku dan Cita-citaku". Tesis. Salatiga: IAIN Salatiga.

Pradana, D. et al. (2020). Nasionalism: Character Education Orientation in Learning Development. Budapest International Research and Critics Institute-Journal (BIRCIJournal). P. 4026-4034.

Kuswana, W.S. (2012). Taksonomi Kognitif. Bandung: PT. Remaja Rosdakarya.

Prasetyo, G. et al. (2019). Modern Paradigm: Democratic Skills in a Higher Order Thinking Skills Frame. Budapest International Research and Critics Institute-Journal (BIRCI-Journal). P. 150-159

Rochmad. (2012). Desain Model Pengembangan Perangkat Pembelajaran Matematika. Jurnal Kreano, 3 (1).

Sa'diyah, H. (2018). Analisis Kebutuhan Pengembangan Perangkat Pembelajaran Berbasis Pendidikan Matematika Realistik Indonesia (PMRI) untuk Meningkatkan Kemampuan Pemecahan Masalah. Prosiding Seminar Nasional Etnomatnesi.

Saifuddin, A. (2009). Reliabilitas dan Validitas. Yogyakarta: Pustaka Pelajar.

Sardiman. (2009). Interaksi dan Motivasi Belajar Mengajar. Jakarta: PT. Rajawali Pers.

Sundayana, R. (2014). Statistika Penelitian Pendidikan. Bandung: Alfabeta.

Trianto. (2011). Model Pembelajaran Terpadu Konsep, Strategi dan Implementasinya dalam Kurikulum Tingkat Satuan Pendidikan (KTSP), Jakarta : Bumi Aksara.

Windrianto, Rusdi, and Syafdi M. (2017). Efektifitas Lembar Kerja Siswa dengan Model Problem Based Learning pada Materi Bangun Ruang Sisi Datar Kelas VIII SMP. Jurnal Penelitian Pembelajaran Matematika Sekolah (JP2MS), 1 (2). 